\title{
Neutrophil Cytosolic Factor 2
}

National Cancer Institute

\section{Source}

National Cancer Institute. Neutrophil Cytosolic Factor 2. NCI Thesaurus. Code C104565.

Neutrophil cytosol factor $2(526 \mathrm{aa}, \sim 60 \mathrm{kDa}$ ) is encoded by the human NCF2 gene. This protein plays a role in the generation of superoxide in neutrophils. 